\title{
ISUP Grade Pattern 5
}

National Cancer Institute

\section{Source}

National Cancer Institute. ISUP Grade Pattern 5. NCI Thesaurus. Code C162658.

Essentially no glandular differentiation, composed of solid sheets, cords, or single cells; comedocarcinoma with central necrosis surrounded by papillary, cribriform, or solid masses. 